\title{
Intronic polymorphisms in TP53 indicate lymph node metastasis in breast cancer
}

\author{
ROMAN HRSTKA ${ }^{1}$, MICHAL BERANEK ${ }^{2}$, KATERINA KLOCOVA ${ }^{1}$, \\ RUDOLF NENUTIL ${ }^{1}$ and BORIVOJ VOJTESEK ${ }^{1}$ \\ ${ }^{1}$ Department of Oncological and Experimental Pathology, Masaryk Memorial Cancer Institute, \\ Zluty kopec 7, 65653 Brno; ${ }^{2}$ Department of Pathophysiology, Faculty of Medicine, \\ Masaryk University, Komenskeho nam. 2, 66243 Brno, Czech Republic
}

Received March 26, 2009; Accepted May 27, 2009

DOI: 10.3892/or_00000556

\begin{abstract}
Recent studies have suggested that genetic polymorphisms in the TP53 pathway influence tumour formation, progression and response to therapy. We analysed the three most common TP53 gene polymorphisms as potential genetic markers to predict the development and prognosis of breast cancer. The incidence of R72P, PIN3 Ins 16bp and PIN6 G13494A polymorphisms was determined in a cohort of 117 breast cancer tissues and 108 control specimens by PCRRFLP. No significant difference was observed in the polymorphism variants in breast cancer specimens compared to controls. Furthermore, no statistically significant association of these polymorphisms with the outcome of the patients was observed. On the other hand we found positive correlation of lymph node metastases with both PIN3 Ins 16bp and PIN6 G13494A polymorphisms. The association of intronic TP53 variants with an aggressive breast cancer phenotype may represent a useful predictive biomarker, particularly in patients of clinical stage I with low or intermediate risk.
\end{abstract}

\section{Introduction}

Breast cancer is the most commonly diagnosed cancer and a predominate cause of death from malignant neoplasms in Czech female population. Although a substantial proportion of breast cancer cases are explained by well-established risk factors (i.e., later age at first pregnancy, nulliparity and firstdegree family history of breast cancer), the reason for the observed worldwide increase in breast cancer incidences is still largely unknown. The molecular biology approaches in a population-based study will provide better mechanistic insights into breast cancer aetiology, prognosis and treatment.

Correspondence to: Dr Borivoj Vojtesek, Masaryk Memorial Cancer Institute, Zluty kopec 7, 65653 Brno, Czech Republic E-mail:vojtesek@mou.cz

Key words: polymorphism, TP53, R72P, PIN3 Ins 16bp, PIN6 G13494A
The TP53 gene represents one of the most studied antioncogenes in tumour biology. In response to stress signals, p53 protein is activated and directs stress-specific transcriptional response programs, leading to i) cell cycle arrest, ii) induction of cell senescence or iii) cellular apoptosis $(1,2)$. TP53 is the most commonly mutated gene found in human cancer $(3,4)$ and selected mutations have already been correlated to specific clinical phenotypes (5). It is therefore feasible that the existence of natural variants of TP53 is linked to the development of specific diseases and they could represent predictive markers for preventive and early intervention strategies. Natural genetic variants of TP53 appear also as good resources to study inter-individual differences in cancer risk and therapeutic response.

A number of polymorphisms have been identified in the TP53 gene (6). Most of these polymorphisms are singlenucleotide polymorphisms (SNPs) affecting a single base and localised within either introns or exons of TP53. Among the polymorphisms found in the coding regions of TP53, only two alter the amino-acid sequence of the protein, proline $(\mathrm{P})$ to serine $(\mathrm{S})$ at residue 47 and arginine $(\mathrm{R})$ to proline $(\mathrm{P})$ at residue 72 . The codon $72 \mathrm{SNP}$ results in a non-conservative change of an arginine (R72) to a proline (P72) that results in a structural change of the protein $(7,8)$ while the polymorphism P47S was identified by Felley-Bosco et al (9) as very rare and undetectable in Caucasians. The frequency of 72 SNP in the population varies from the equator to higher latitudes, suggesting a selection pressure upon these two forms of p53 protein (10). Moreover, several lines of evidence suggest that this polymorphism can play a role in apoptosis and cancer formation in humans (11-13).

The IARC TP53 Mutation Database describes 29 common polymorphisms in the non-coding region of TP53, of which two have been suggested to affect the level of expression of p53 as well as its function: i) a 16bp duplication in intron 3 localised at nucleotide 11951 (PIN3 Ins 16bp) (14), and ii) a $\mathrm{G}$ to $\mathrm{A}$ transversion in intron 6 at nucleotide 13494 (PIN6 G13494A) often reported as MspI (15) or Bst NI/NciI polymorphism (16).

We performed a hospital-based study in breast cancer patients to evaluate the potential modifying role of the three highly common genetic polymorphisms in the TP53 gene. 
We also took into account the potential interaction between these polymorphisms and the known clinicopathological features that are important prognostic markers in breast tumours. The data we present in this work suggest that analysis of polymorphisms in TP53 gene can represent an additional useful tool for prognosis prediction.

\section{Materials and methods}

Clinical samples. One hundred and seventeen breast cancer tissue samples were obtained from female patients in clinical stages I or II without previous therapy, diagnosed and treated at Masaryk Memorial Cancer Institute during the period 2004 to 2005 . The lumpectomy or mastectomy resection specimens were received within 20 min of surgical removal and immediately evaluated by a pathologist. Tissue pieces of approximately $3 \times 3 \times 8 \mathrm{~mm}$ were cut from redundant tumour tissue after standard surgicopathological processing, snap frozen in liquid nitrogen and stored at $-80^{\circ} \mathrm{C}$. These specimens were subsequently used for DNA purification by DNeasy tissue kit (Qiagen). Routinely prepared formalin-fixedparaffin-embedded (FFPE) tissue blocks taken in parallel, were fixed in $4 \%$ neutral formaldehyde for $24 \mathrm{~h}$. Sections were cut at a thickness of $4 \mu \mathrm{m}$ and collected onto positively charged slides for immunohistochemistry. The main clinicopathological variables including tumour type, grade and nuclear grade according to Elston-Ellis (17), estrogen receptor (ER), progesterone receptor (PR) and HER2/neu status, were extracted from pathological records obtained from the Masaryk Memorial Cancer Institute database. Ethical permission was granted following review at the Masaryk Memorial Cancer Institute and all patients gave written consent. DNA from one hundred and eight control samples was extracted from peripheral blood of healthy female volunteers with no oncological diagnosis to date.

Immunohistochemistry and FISH. Additional immunohistochemistry and fluorescence in situ hybridization (FISH) were performed to estimate cyclin D1 overexpression and amplification, and Ki67 expression. The antibodies used in this study are listed below: rabbit monoclonal cyclin D1 antibody (Lab Vision) and MIB1 mouse monoclonal antibody which recognises Ki67 (DakoCytomation). After removal of paraffin wax and rehydration, endogenous peroxidase activity was blocked with $3 \%$ hydrogen peroxide in phosphate buffered saline (PBS), pH 7.5 for $15 \mathrm{~min}$. Antigen retrieval was performed by heating sections in $1 \mathrm{mM}$ EDTA-NaOH buffer (pH 8.0) for $40 \mathrm{~min}$ at $93^{\circ} \mathrm{C}$. Primary antibodies were diluted in antibody diluent (DakoCytomation) and applied overnight at $4^{\circ} \mathrm{C}$. Reactive sites were identified with biotinylated antimouse or anti-rabbit secondary antibodies and peroxidase $\mathrm{ABC}$ reagents (Vector-Elite) according to the manufacturer's instructions and peroxidase activity was visualised with $\mathrm{DAB}+$ reagents (DakoCytomation). Sections were counterstained with Gills haematoxylin. FISH evaluations were performed using Vysis LSI Cyclin D1/CEP11 and PathVysion HER-2 DNA Probe Kits (Abbott Laboratories) according to the manufacturer's instructions.

TP53 sequencing. Total cellular RNA was extracted using TRI Reagent (MRC). TP53 mRNA from tumour tissue was amplified using the SuperScript ${ }^{\mathrm{TM}}$ III One Step RT-PCR System with Platinum ${ }^{\circledR}$ Taq High Fidelity (Invitrogen), sense primer: 5'-TCCCCTCCCATGTGCTCAAGACTG-3' and antisense primer: 5'-GGAGCCCCGGGACAAAGCAAA TGG-3'. PCR products were purified by MinElute ${ }^{\mathrm{TM}}$ PCR Purification kit (Qiagen) and sequenced using the ABI PRISM BigDye $^{\circledR}$ Terminator v 3.1 Cycle Sequencing Kit on an ABI 3130 genetic analyser (Applied Biosystems).

Determination of TP53 polymorphisms. R72P polymorphism was assessed by PCR-RFLP technique as described previously (18). The codon 72 SNP determination was compared to TP53 sequencing and resulted with $100 \%$ hit rate. The PIN3 Ins 16bp was genotyped by a simple PCR method, as performed previously (14) and PIN6 G13494A polymorphism was detected by PCR amplification of genomic DNA followed by Bst NI digestion according to (16).

Statistical methods. Statistical analysis was done using Statistica 8.0 (StatSoft). $\chi^{2}$ test was used to evaluate association of TP53 polymorphisms with breast cancer risk. The relationship between particular genotypes and multiple clinicopathological variables was determined using KruskalWallis test. The relationship between allelic frequencies of polymorphisms and lymph node metastases was assessed using Mann-Whitney U test. Disease-free survival (DFS) curves were generated by the Kaplan-Meier method and verified by the log-rank test.

\section{Results}

TP53 genotyping. The distribution of polymorphisms R72P, PIN3 Ins 16bp and PIN6 G13494A in TP53 gene was assessed in a total of 117 female patients with breast cancer (mean age of 59.5 years, with an age range of 22-84 years) and compared to 108 healthy controls (mean age of 58.86 years, with an age range of 24-88 years) with respect to possible association with increased risk of tumour development. According to $\chi^{2}$ test, no significant differences between the genotypes of patients and controls or allele frequencies were found for all three polymorphisms analysed in this study, except PIN6 G13494A heterozygotes (Table I). Additionally we analysed genotype effects of these polymorphisms on breast cancer risk (Table II), where only genotypes with frequency at least $5 \%$ were calculated. Comparing the common TP53 R/RA1/A1-G/G genotype with the other observed genotypes we did not find statistically significant difference between the breast cancer cases and control group.

Relationship between 553 polymorphisms and clinicopathological variables. The age of patients at diagnosis ranged from 22 to 84 years, with a mean age of 59.5 years. The relationship between age at onset and different genotype polymorphisms analysed using non-parametric Kruskal-Wallis test also showed no statistically significant associations between any genotype and an earlier age at onset. The relationships between studied TP53 polymorphisms and other various clinicopathological parameters determined in our group of patients are shown in Table III, where 79 patients $(67.5 \%)$ had infiltrative ductal carcinoma, $23(19.7 \%)$ had lobular carcinoma and 15 patients $(12.8 \%)$ had other types of breast cancer. 
Table I. TP53 R72P, PIN3 Ins16 bp and PIN6 G/C genotypic and allelic frequencies.

\begin{tabular}{|c|c|c|c|c|c|c|}
\hline \multirow[b]{2}{*}{$\begin{array}{l}\text { TP53 } \\
\text { polymorphism }\end{array}$} & & \multirow[b]{2}{*}{ Genotype } & \multicolumn{2}{|c|}{ Frequency $(\%)$} & \multicolumn{2}{|c|}{ Breast cancer risk } \\
\hline & & & Tumours & Controls & $\chi^{2}(\mathrm{p}$-value $)$ & OR $(95 \% \mathrm{CI})$ \\
\hline \multicolumn{7}{|l|}{ R72P } \\
\hline & & $\mathrm{R} / \mathrm{R}$ & $62(53.0)$ & $55(50.9)$ & Ref. & Ref. \\
\hline & & $\mathrm{R} / \mathrm{P}$ & $15(12.8)$ & $8(7.4)$ & 0.281 & $1.66(0.66-4.22)$ \\
\hline & & $\mathrm{P} / \mathrm{P}$ & $40(34.2)$ & $45(41.7)$ & 0.405 & $0.79(0.45-1.38)$ \\
\hline & Alleles & & & & & \\
\hline & & $\mathrm{R}$ & $139(59.4)$ & $118(54.6)$ & Ref. & Ref. \\
\hline & & $\mathrm{P}$ & $95(40.6)$ & $98(45.4)$ & 0.307 & $0.82(0.57-1.20)$ \\
\hline \multicolumn{7}{|l|}{ PIN3 Ins 16bp } \\
\hline & & $\mathrm{A} 1 / \mathrm{A} 1$ & $81(69.2)$ & $81(75.0)$ & Ref. & Ref. \\
\hline & & $\mathrm{A} 1 / \mathrm{A} 2$ & $32(27.4)$ & $24(22.2)$ & 0.356 & $1.33(0.72-2.46)$ \\
\hline & & $\mathrm{A} 2 / \mathrm{A} 2$ & $4(3.4)$ & $3(2.8)$ & 0.711 & $1.33(0.29-6.15)$ \\
\hline & Alleles & & & & & \\
\hline & & A1 & $194(82.9)$ & $186(86.1)$ & Ref. & Ref. \\
\hline & & $\mathrm{A} 2$ & $40(17.1)$ & $30(13.9)$ & 0.349 & $1.28(0.76-2.14)$ \\
\hline \multicolumn{7}{|l|}{ PIN6 G13494A } \\
\hline & & $\mathrm{G} / \mathrm{G}$ & $76(65.0)$ & $83(76.85)$ & Ref. & Ref. \\
\hline & & $\mathrm{G} / \mathrm{A}$ & $39(33.3)$ & $23(21.3)$ & 0.044 & $1.85(1.01-3.38)$ \\
\hline & & $\mathrm{A} / \mathrm{A}$ & $2(1.7)$ & $2(1.85)$ & 0.931 & $1.09(0.15-7.95)$ \\
\hline & Alleles & & & & & \\
\hline & & $\mathrm{G}$ & $191(81.6)$ & $189(87.5)$ & Ref. & Ref. \\
\hline & & A & 43 (18.4) & $27(12.5)$ & 0.086 & $1.58(0.94-2.65)$ \\
\hline
\end{tabular}

A1, wt variant of intron 3; A2, 16bp insertion in intron 3.

Table II. Genotype frequencies between R72P, PIN3 Ins16bp and PIN6 G/A polymorphisms.

\begin{tabular}{|c|c|c|c|c|}
\hline \multirow[b]{2}{*}{ Genotypes } & \multicolumn{2}{|c|}{ Frequency (\%) } & \multicolumn{2}{|c|}{ Breast cancer risk } \\
\hline & Tumours & Controls & $\chi^{2}(\mathrm{p}$-value $)$ & OR $(95 \% \mathrm{CI})$ \\
\hline $\mathrm{R} / \mathrm{R}-\mathrm{A} 1 / \mathrm{A} 1-\mathrm{G} / \mathrm{G}$ & $52(44.4)$ & $51(47.2)$ & Ref. & Ref. \\
\hline R/P-A1/A2-G/A & $20(17.1)$ & $15(13.9)$ & 0.496 & $1.31(0.60-2.83)$ \\
\hline R/P-A1/A1-G/A & $6(5.1)$ & $1(0.9)$ & 0.071 & $5.88(0.68-50.62)$ \\
\hline $\mathrm{R} / \mathrm{P}-\mathrm{A} 1 / \mathrm{A} 1-\mathrm{G} / \mathrm{G}$ & $14(12.0)$ & $26(24.1)$ & 0.096 & $0.53(0.25-1.12)$ \\
\hline P/P-A1/A2-G/A & $6(5.1)$ & $5(4.6)$ & 0.798 & $1.18(0.34-4.1)$ \\
\hline $\mathrm{P} / \mathrm{P}-\mathrm{A} 2 / \mathrm{A} 2-\mathrm{A} / \mathrm{A}$ & $2(1.7)$ & $1(0.9)$ & - & \\
\hline P/P-A1/A1-G/A & $1(0.9)$ & - & - & \\
\hline $\mathrm{P} / \mathrm{P}-\mathrm{A} 1 / \mathrm{A} 1-\mathrm{G} / \mathrm{G}$ & $6(5.1)$ & $2(1.9)$ & 0.181 & $2.94(0.57-15.26)$ \\
\hline $\mathrm{R} / \mathrm{R}-\mathrm{A} 1 / \mathrm{A} 2-\mathrm{G} / \mathrm{A}$ & $3(2.6)$ & - & - & \\
\hline R/R-A1/A2-G/G & $3(2.6)$ & $3(2.8)$ & - & \\
\hline R/R-A2/A2-G/A & $1(0.9)$ & - & - & \\
\hline $\mathrm{R} / \mathrm{R}-\mathrm{A} 2 / \mathrm{A} 2-\mathrm{G} / \mathrm{G}$ & $1(0.9)$ & - & - & \\
\hline $\mathrm{R} / \mathrm{R}-\mathrm{A} 1 / \mathrm{A} 1-\mathrm{G} / \mathrm{A}$ & $2(1.7)$ & $1(0.9)$ & - & \\
\hline R/P-A1/A2-G/G & - & $1(0.9)$ & - & \\
\hline $\mathrm{R} / \mathrm{P}-\mathrm{A} 2 / \mathrm{A} 2-\mathrm{G} / \mathrm{A}$ & - & $1(0.9)$ & - & \\
\hline $\mathrm{R} / \mathrm{P}-\mathrm{A} 2 / \mathrm{A} 2-\mathrm{A} / \mathrm{A}$ & - & $1(0.9)$ & - & \\
\hline
\end{tabular}

A1, wt variant of intron 3; A2, 16bp insertion in intron 3. 
Table III. Association of clinicopathological variables with different TP53 genotypes.

\begin{tabular}{|c|c|c|c|c|}
\hline Variable & $\begin{array}{l}\text { Total of } \\
\text { samples }\end{array}$ & $\begin{array}{l}\text { R72P } \\
\text { p-level }\end{array}$ & $\begin{array}{l}\text { PIN3 Ins 16bp } \\
\text { p-level }\end{array}$ & $\begin{array}{c}\text { PIN6 G13494A } \\
\text { p-level }\end{array}$ \\
\hline \multicolumn{5}{|l|}{ Histologic grade } \\
\hline G1 & 33 & & & \\
\hline $\mathrm{G} 2$ & 41 & 0.1120 & 0.6418 & 0.3339 \\
\hline G3 & 43 & & & \\
\hline \multicolumn{5}{|l|}{ Nodal status $^{\mathrm{a}}$} \\
\hline \multirow[t]{2}{*}{ Negative } & 47 & & & \\
\hline & & 0.3869 & 0.0193 & 0.0293 \\
\hline Positive & 70 & & & \\
\hline Tumour size ${ }^{b}$ & 117 & 0.7165 & 0.9760 & 0.9711 \\
\hline \multicolumn{5}{|l|}{ ER status $^{\mathrm{a}}$} \\
\hline \multirow[t]{2}{*}{ Negative } & 20 & & & \\
\hline & & 0.4961 & 0.8926 & 0.7456 \\
\hline Positive & 97 & & & \\
\hline \multicolumn{5}{|l|}{ PgR status ${ }^{\mathrm{a}}$} \\
\hline \multirow[t]{2}{*}{ Negative } & 26 & & & \\
\hline & & 0.8469 & 0.3662 & 0.4969 \\
\hline Positive & 91 & & & \\
\hline \multicolumn{5}{|l|}{ Her2 amplification ${ }^{a}$} \\
\hline \multirow[t]{2}{*}{ Negative } & 91 & & & \\
\hline & & 0.9369 & 0.7158 & 0.7944 \\
\hline Positive & 14 & & & \\
\hline \multicolumn{5}{|l|}{ CD1 amplification ${ }^{a}$} \\
\hline \multirow[t]{2}{*}{ Negative } & 87 & & & \\
\hline & & 0.2274 & 0.8246 & 0.7128 \\
\hline Positive & 15 & & & \\
\hline $\begin{array}{l}\text { CD1 expression } \\
(\%)\end{array}$ & 117 & 0.6848 & 0.3808 & 0.6312 \\
\hline $\begin{array}{l}\text { Ki67 expression }{ }^{\mathrm{b}} \\
(\%)\end{array}$ & 117 & 0.1069 & 0.9196 & 0.5551 \\
\hline
\end{tabular}

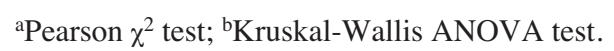

These data reveal neither oestrogen receptor expression nor progesterone receptor expression associated with presence of a specific genotype. Similarly no relationship was found between genotype frequency and tumour size, grade, histological type of tumour, Ki67 and cyclin D1 expression. Evaluation of the lymph node status revealed a statistically significant relationship between $16 \mathrm{bp}$ duplication in intron 3 and development of lymph node metastases ( $\mathrm{p}=0.019, \chi^{2}$ test). The frequencies for particular intron 3 genotypes with respect to lymph node involvement are summarized in Table IV. The allelic frequencies were also strongly associated with node metastases ( $p=0.025$, Mann-Whitney $U$ test). A statistically significant association was also found between patients with lymph node involvement and PIN6 G13494A
Table IV. Observed frequencies.

\begin{tabular}{lrrrrrrrr}
\hline & \multicolumn{3}{c}{ PIN3 Ins 16bp } & & \multicolumn{3}{c}{ PIN6 G13494A } \\
\cline { 2 - 3 } \cline { 7 - 8 } $\begin{array}{l}\text { Nodal } \\
\text { status }\end{array}$ & A1/A1 & A1/A2 & A2/A2 & & G/G & G/A & A/A \\
\hline Negative & 39 & 8 & 0 & & 37 & 10 & 0 \\
Positive & 42 & 24 & 4 & & 39 & 29 & 2 \\
\hline
\end{tabular}

polymorphism ( $\mathrm{p}=0.029, \chi^{2}$ test). Similarly, allelic frequencies were also significantly associated with node metastases ( $\mathrm{p}=0.030$, Mann-Whitney U test). 
Table V. Association of clinicopathological variables with different TP53 genotypes in tumours bearing wt p53.

\begin{tabular}{|c|c|c|c|c|}
\hline Variable & $\begin{array}{l}\text { Total of } \\
\text { samples }\end{array}$ & $\begin{array}{l}\text { R72P } \\
\text { p-level }\end{array}$ & $\begin{array}{l}\text { PIN3 Ins 16bp } \\
\text { p-level }\end{array}$ & $\begin{array}{c}\text { PIN6 G13494A } \\
\text { p-level }\end{array}$ \\
\hline \multicolumn{5}{|l|}{ Histologic grade $^{\mathrm{a}}$} \\
\hline G1 & 28 & & & \\
\hline G2 & 34 & 0.5836 & 0.6835 & 0.4430 \\
\hline G3 & 20 & & & \\
\hline \multicolumn{5}{|l|}{ Nodal status $^{\mathrm{a}}$} \\
\hline \multirow[t]{2}{*}{ Negative } & 32 & & & \\
\hline & & 0.4016 & 0.0402 & 0.0269 \\
\hline Positive & 50 & & & \\
\hline Tumour size ${ }^{b}$ & 82 & 0.4509 & 0.2228 & 0.9347 \\
\hline \multicolumn{5}{|l|}{ ER status $^{\mathrm{a}}$} \\
\hline \multirow[t]{2}{*}{ Negative } & 7 & & & \\
\hline & & 0.7169 & 0.9448 & 0.6453 \\
\hline Positive & 75 & & & \\
\hline \multicolumn{5}{|l|}{ PgR status ${ }^{a}$} \\
\hline \multirow[t]{2}{*}{ Negative } & 10 & & & \\
\hline & & 0.5013 & 0.9302 & 0.6445 \\
\hline Positive & 72 & & & \\
\hline \multicolumn{5}{|l|}{ Her2 amplification ${ }^{a}$} \\
\hline \multirow[t]{2}{*}{ Negative } & 63 & & & \\
\hline & & 0.3049 & 0.8880 & 0.9563 \\
\hline Positive & 8 & & & \\
\hline \multicolumn{5}{|l|}{ CD1 amplification ${ }^{\mathrm{a}}$} \\
\hline \multirow[t]{2}{*}{ Negative } & 61 & & & \\
\hline & & 0.3043 & 0.8962 & 0.4821 \\
\hline Positive & 8 & & & \\
\hline $\begin{array}{l}\text { CD1 expression } \\
(\%)\end{array}$ & 68 & 0.8452 & 0.2512 & 0.6718 \\
\hline $\begin{array}{l}\text { Ki67 expression } \\
(\%)\end{array}$ & 82 & 0.7580 & 0.2708 & 0.5665 \\
\hline
\end{tabular}

${ }^{\mathrm{a}} \chi^{2}$ test; ${ }^{\mathrm{b} K r u s k a l-W a l l i s ~ A N O V A ~ t e s t . ~}$

TP53 polymorphisms, mutations and prognosis. TP53 gene mutations were identified in $29.9 \%$ tumours and only specimens bearing wild-type p53 have been used for further analysis to determine the role of the three studied polymorphisms in cells with functional p53 protein. Analogous to analysis of all specimens regardless of p53 status, no significant associations between the analysed polymorphisms and other clinicopathological variables were found, except development of lymph node metastases (Table V).

Interestingly, a significant relationship between allelic frequency of intronic polymorphism PIN3 Ins 16bp and lymph node involvement was also found ( $p=0.0169$ for PIN3 A 2 allele, $\chi^{2}$ test) in the group of wt p53 carriers. Determination of PIN6 G13494A allelic frequency revealed only
Table VI. Observed frequencies in wt p53 carriers.

\begin{tabular}{lcccccccc}
\hline & \multicolumn{3}{c}{ PIN3 Ins 16bp } & & \multicolumn{3}{c}{ PIN6 G13494A } \\
\cline { 2 - 3 } \cline { 7 - 8 } $\begin{array}{l}\text { Nodal } \\
\text { status }\end{array}$ & A1/A1 & A1/A2 & A2/A2 & & G/G & G/A & A/A \\
\hline Negative & 27 & 5 & 0 & & 25 & 7 & 0 \\
Positive & 29 & 20 & 1 & & 27 & 23 & 0
\end{tabular}

marginal statistical significance $(\mathrm{p}=0.0513$ for PIN6 13494A allele, $\chi^{2}$ test) respectively. Observed frequencies are shown in Table VI. 
The analysis of the link between SNPs and breast cancer survival found no association between all three polymorphisms and disease-free survival (DFS) (data not shown).

\section{Discussion}

Cancers harbour germ line and/or somatic mutations in selected genes, resulting in disruption of signalling pathways involved in regulation of the homeostatic mechanisms in the cell. In this respect, the most interesting candidate genes include those that mediate a wide range of functions. The major risk factor for breast cancer can be linked to reproductive events that influence the lifetime levels of hormones. However, a large percentage of breast cancer cases cannot be explained by these risk factors. The identification of susceptibility factors that predispose individuals to this type of cancer will give further insight into the aetiology of this malignancy and provide targets for the future development of therapeutic approaches. Polymorphisms in the TP53 gene as the frequent site of mutations are considered as one of those potential factors (19). A large number of studies have assessed the prognostic and predictive role of TP53 polymorphisms in breast cancer yielding conflicting results (20).

We analysed R72P, PIN3 Ins 16bp and PIN6 G13494A polymorphisms in TP53 gene and their association with an increased risk of tumour development, clinicopathological variables and prognosis in sporadic breast cancers. Concerning the R72P polymorphism, we did not find any association between this polymorphism and breast cancer risk in our set of samples. Additionally no relation was observed between $\mathrm{R} 72 \mathrm{P}$ variants and other clinicopathological variables including DFS. These results are in agreement with other studies (21-23), nevertheless there are other reports showing important role for this polymorphism in breast cancers $(24,25)$. These differences in findings can be explained by a more complex role of p53 R72P polymorphism in carcinogenesis (26). Polymorphisms in the non-coding region of TP53 gene could also play an important role in the regulation of gene expression. Boldrini et al (27) analysed combined effect of the TP53 codon 72 and PIN3 polymorphisms in patients with nonsmall cell lung cancer and showed evidence for dosageeffects of these polymorphisms. Patients ranging from zero to two TP53 variant alleles tended to exhibit a better prognosis, compared to patients with three or four variants. We also analysed combined genotypes presented in individuals with respect to increased breast cancer risk (Table II) as well as DFS (data not shown). However, we did not find significant association of any genotype with both breast cancer risk and DFS, possibly due to short follow-up of our set of patients. Other published data suggest that combination of rare PIN3 A2 and PIN6 13494A alleles may modify the risk for breast cancer (28-30). Our results revealed only marginal association between PIN6 allele A and breast cancer incidence ( $\mathrm{p}=0.086)$. Nevertheless, predisposition of particular intronic haplotypes to breast cancer incidence was not confirmed in our study (data not shown).

Costa et al (23) show PIN3 Ins16bp polymorphism as a real risk modifier in breast cancer disease, either in sporadic and familial breast cancer, and moreover reveal association of this polymorphism with higher incidence of lymph node metastases. These data are in agreement with Gemignani et al, who showed that 16bp duplication in intron 3 is associated with increased risk of colorectal cancer and with reduced levels of TP53 mRNA, suggesting that the PIN3 A2 allele has reduced mRNA stability (31). However, the molecular mechanism as well as biological effect of this polymorphism has not been fully elucidated to date. Interestingly, we found that both intronic polymorphisms PIN3 Ins 16bp and PIN6 G13494A are significantly associated with higher incidence of lymph node metastases. These findings provide further evidence that these genotype variants are associated with a more aggressive tumour phenotype.

In summary, our results show no association of breast cancer risk with R72P, PIN3 Ins 16bp and PIN6 G13494A polymorphisms in TP53 gene. On the other hand we found significant association between the presence of lymph node metastases and both intron 3 16bp duplication and intron 6 13494A allele variant. These findings provide support for potential prognostic effects of these two intronic polymorphisms in breast cancer.

Despite our best efforts, a significant proportion of patients suffering from breast carcinoma will develop advanced disease and we do not currently have sufficient reliable tools to predict who these patients are. For this reason, additional independent predictive bio-markers are required to select patients that will benefit from more intensive treatment and monitoring to prevent tumour progression. This applies especially to the group of patients of clinical stage I with low or intermediate risk according to the current NCI or St. Gallen criteria. In our study, TP53 intron 3 16bp duplication and intron 6 13494A allele variant are significantly related to the presence of lymph node involvement, which is the strongest known prognostic indicator in low grade ER positive tumours. Further studies focused on the prognostic impact of these polymorphisms in representative datasets should be performed to elucidate their potential to serve as predictors of advanced disease development.

\section{Acknowledgements}

We would like to thank Tamara Smerdova and Eva Michalova for their excellent technical assistance and Dr P.J. Coates for a critical reading of the manuscript. This study was supported by the IGA MZ CR NS/9812-4.

\section{References}

1. Vogelstein B, Lane D and Levine AJ: Surfing the p53 network. Nature 408: 307-310, 2000.

2. Jin S and Levine AJ: The p53 functional circuit. J Cell Sci 114: 4139-4140, 2001.

3. Nigro JM, Baker SJ, Preisinger AC, et al: Mutations in the p53 gene occur in diverse human tumour types. Nature 342: 705-708, 1989.

4. Levine AJ, Momand J and Finlay CA: The p53 tumour suppressor gene. Nature 351: 453-456, 1991.

5. Alsner J, Yilmaz M, Guldberg P, Hansen LL and Overgaard J: Heterogeneity in the clinical phenotype of TP53 mutations in breast cancer patients. Clin Cancer Res 6: 3923-3931, 2000.

6. Olivier M, Eeles R, Hollstein M, Khan MA, Harris CC and Hainaut P: The IARC TP53 database: new online mutation analysis and recommendations to users. Hum Mutat 19: 607-614, 2002 . 
7. Harris N, Brill E, Shohat O, et al: Molecular basis for heterogeneity of the human p53 protein. Mol Cell Biol 6 : 4650-4656, 1986.

8. Matlashewski GJ, Tuck S, Pim D, Lamb P, Schneider J and Crawford LV: Primary structure polymorphism at amino acid residue 72 of human p53. Mol Cell Biol 7: 961-963, 1987.

9. Felley-Bosco E, Weston A, Cawley HM, Bennett WP and Harris CC: Functional studies of a germ-line polymorphism at codon 47 within the p53 gene. Am J Hum Genet 53: 752-759, 1993.

10. Beckman G, Birgander R, Sjalander A, et al: Is p53 polymorphism maintained by natural selection? Hum Hered 44 266-270, 1994

11. Baptiste N, Friedlander P, Chen X and Prives C: The prolinerich domain of p53 is required for cooperation with antineoplastic agents to promote apoptosis of tumor cells. Oncogene 21: 9-21, 2002

12. Dumont P, Leu JI, Della Pietra AC III, George DL and Murphy M: The codon 72 polymorphic variants of $\mathrm{p} 53$ have markedly different apoptotic potential. Nat Genet 33: 357-365, 2003

13. Marin MC, Jost CA, Brooks LA, et al: A common polymorphism acts as an intragenic modifier of mutant p53 behaviour. Nat Genet 25: 47-54, 2000

14. Lazar V, Hazard F, Bertin F, Janin N, Bellet D and Bressac B: Simple sequence repeat polymorphism within the p53 gene. Oncogene 8: 1703-1705, 1993

15. McDaniel T, Carbone D, Takahashi T, et al: The MspI polymorphism in intron 6 of p53 (TP53) detected by digestion of PCR products. Nucleic Acids Res 19: 4796, 1991.

16. Chumakov PM and Jenkins JR: BstNI/NciI polymorphism of the human p53 gene (TP53). Nucleic Acids Res 19: 6969, 1991.

17. Elston CW and Elis IO: Assessment of histological grade. In: The Breast. Elston CW and Elis IO (eds). Churchill Livingstone, Edinburgh, pp365-384, 1998.

18. Zhu ZZ, Cong WM, Liu SF, et al: A p53 polymorphism modifies the risk of hepatocellular carcinoma among noncarriers but not carriers of chronic hepatitis B virus infection. Cancer Lett 229: 77-83, 2005.

19. Pharoah PD, Day NE and Caldas C: Somatic mutations in the p53 gene and prognosis in breast cancer: a meta-analysis. Br J Cancer 80: 1968-1973, 1999
20. Hrstka R, Coates PJ and Vojtesek B: Polymorphisms in p53 and the 553 pathway: roles in cancer susceptibility and response to treatment. J Cell Mol Med 13: 440-453, 2009.

21. Tommiska J, Eerola H, Heinonen M, et al: Breast cancer patients with p53 Pro72 homozygous genotype have a poorer survival. Clin Cancer Res 11: 5098-5103, 2005.

22. Khadang B, Fattahi MJ, Talei A, Dehaghani AS and Ghaderi A: Polymorphism of TP53 codon 72 showed no association with breast cancer in Iranian women. Cancer Genet Cytogenet 173: 38-42, 2007.

23. Costa S, Pinto D, Pereira D, et al: Importance of TP53 codon 72 and intron 3 duplication 16bp polymorphisms in prediction of susceptibility on breast cancer. BMC Cancer 8: 32, 2008.

24. Buyru N, Tigli H and Dalay N: P53 codon 72 polymorphism in breast cancer. Oncol Rep 10: 711-714, 2003.

25. Papadakis EN, Dokianakis DN and Spandidos DA: p53 codon 72 polymorphism as a risk factor in the development of breast cancer. Mol Cell Biol Res Commun 3: 389-392, 2000.

26. Soussi $\mathrm{T}$ and Wiman KG: Shaping genetic alterations in human cancer: the p53 mutation paradigm. Cancer Cell 12: 303-312, 2007.

27. Boldrini L, Gisfredi S, Ursino S, et al: Effect of the p53 codon 72 and intron 3 polymorphisms on non-small cell lung cancer (NSCLC) prognosis. Cancer Invest 26: 168-172, 2008.

28. Wang-Gohrke S, Rebbeck TR, Besenfelder W, Kreienberg R and Runnebaum IB: p53 germline polymorphisms are associated with an increased risk for breast cancer in German women. Anticancer Res 18: 2095-2099, 1998.

29. Mahasneh AA and Abdel-Hafiz SS: Polymorphism of p53 gene in Jordanian population and possible associations with breast cancer and lung adenocarcinoma. Saudi Med J 25: 1568-1573, 2004.

30. Sjalander A, Birgander R, Hallmans G, et al: p53 polymorphisms and haplotypes in breast cancer. Carcinogenesis 17 : 1313-1316, 1996

31. Gemignani F, Moreno V, Landi S, et al: A TP53 polymorphism is associated with increased risk of colorectal cancer and with reduced levels of TP53 mRNA. Oncogene. 23: 1954-1956, 2004. 